\section{Author Correction: Dense sampling of bird diversity increases power of comparative genomics}

https://doi.org/10.1038/s41586-021-03473-8

Correction to: Nature https://doi.org/10.1038/s41586-020-2873-9

Published online 11 November 2020

Open access

Check for updates

Shaohong Feng, Josefin Stiller, Yuan Deng, Joel Armstrong, Qi Fang, Andrew Hart Reeve, Duo Xie, Guangji Chen, Chunxue Guo, Brant C. Faircloth, Bent Petersen, Zongji Wang, Qi Zhou, Mark Diekhans, Wanjun Chen, Sergio Andreu-Sánchez, Ashot Margaryan, Jason Travis Howard, Carole Parent, George Pacheco, Mikkel-Holger S. Sinding, Lara Puetz, Emily Cavill, Ângela M. Ribeiro, Leopold Eckhart, Jon Fjeldså, Peter A. Hosner, Robb T. Brumfield, Les Christidis, Mads F. Bertelsen, Thomas Sicheritz-Ponten, Dieter Thomas Tietze, Bruce C. Robertson, Gang Song, Gerald Borgia, Santiago Claramunt, Irby J. Lovette, Saul J. Cowen, Peter Njoroge, John Philip Dumbacher, Oliver A. Ryder, Jérôme Fuchs, Michael Bunce, David W. Burt, Joel Cracraft, Guanliang Meng, Shannon J. Hackett, Peter G. Ryan, Knud Andreas Jønsson, Ian G. Jamieson, Rute R. da Fonseca, Edward L. Braun, Peter Houde, Siavash Mirarab, Alexander Suh, Bengt Hansson, Suvi Ponnikas, Hanna Sigeman, Martin Stervander, Paul B. Frandsen, Henriette van der Zwan, Rencia van der Sluis, Carina Visser, Christopher N. Balakrishnan, Andrew G. Clark, John W. Fitzpatrick, Reed Bowman, Nancy Chen, Alison Cloutier, Timothy B. Sackton, Scott V. Edwards, Dustin J. Foote, Subir B. Shakya, Frederick H. Sheldon, Alain Vignal, André E. R. Soares, Beth Shapiro, Jacob González-Solís, Joan Ferrer-Obiol, Julio Rozas, Marta Riutort, Anna Tigano,
Vicki Friesen, Love Dalén, Araxi O. Urrutia, Tamás Székely, Yang Liu, Michael G. Campana, André Corvelo, Robert C. Fleischer, Kim M. Rutherford, Neil J. Gemmell, Nicolas Dussex, Henrik Mouritsen, Nadine Thiele, Kira Delmore, Miriam Liedvogel, Andre Franke, Marc P. Hoeppner, Oliver Krone, Adam M. Fudickar, Borja Milá, Ellen D. Ketterson, Andrew Eric Fidler, Guillermo Friis, Ángela M. Parody-Merino, Phil F. Battley, Murray P. Cox, Nicholas Costa Barroso Lima, Francisco Prosdocimi, Thomas Lee Parchman, Barney A. Schlinger, Bette A. Loiselle, John G. Blake, Haw Chuan Lim, Lainy B. Day, Matthew J. Fuxjager, Maude W. Baldwin, Michael J. Braun, Morgan Wirthlin, Rebecca B. Dikow, T. Brandt Ryder, Glauco Camenisch, Lukas F. Keller, Jeffrey M. DaCosta, Mark E. Hauber, Matthew I. M. Louder, Christopher C. Witt, Jimmy A. McGuire, Joann Mudge, Libby C. Megna, Matthew D. Carling, Biao Wang, Scott A. Taylor, Glaucia Del-Rio, Alexandre Aleixo, Ana Tereza Ribeiro Vasconcelos, Claudio V. Mello, Jason T. Weir, David Haussler, Qiye Li, Huanming Yang, Jian Wang, Fumin Lei, Carsten Rahbek, M. Thomas P. Gilbert, Gary R. Graves, Erich D. Jarvis, Benedict Paten \& Guojie Zhang

In Supplementary Table 1 of this Article, 23 samples (B10K-DU-029-32, B10K-DU-029-33, B10K-DU-029-36 to B10K-DU-029-44, B10K-DU029-46,B10K-DU-029-47,B10K-DU-029-49 toB10K-DU-029-53, B10K-DU029-75 to B10K-DU-029-77, B10K-DU-029-80, and B10K-DU-030-03; styled in boldface in the revised table) were assigned to the incorrect institution. Supplementary Table 1 has been amended to reflect the correct source institution for these samples, and associated data (tissue, museum ID/source specimen ID, site, state/province, latitude, longitude, date collected and sex) have been updated accordingly. The original table is provided as Supplementary Information to this Amendment, and the original Article has been corrected online.

Supplementary information is available in the online version of this Amendment.

Open Access This article is licensed under a Creative Commons Attribution 4.0 International License, which permits use, sharing, adaptation, distribution and reproduction in any medium or format, as long as you give appropriate credit to the original author(s) and the source, provide a link to the Creative Commons license, and indicate if changes were made. The images or other third party material in this article are included in the article's Creative Commons license, unless indicated otherwise in a credit line to the material. If material is not included in the article's Creative Commons license and your intended use is not permitted by statutory regulation or exceeds the permitted use, you will need to obtain permission directly from the copyright holder. To view a copy of this license, visit http://creativecommons.org/licenses/by/4.0/. 